American Political Science Association

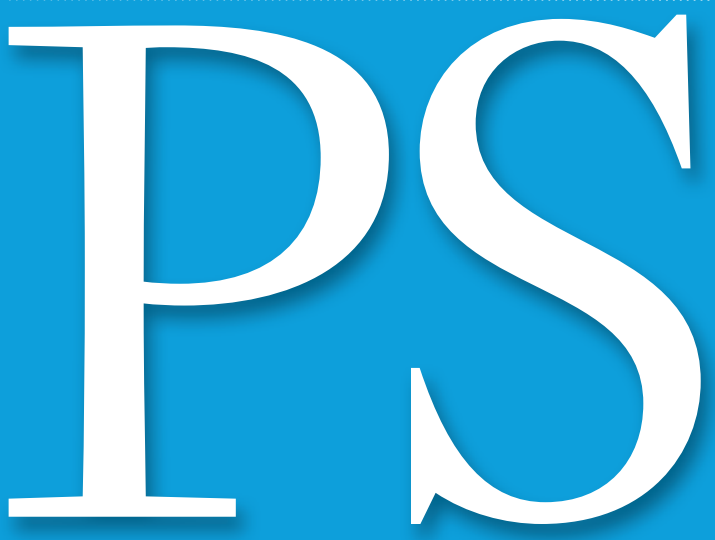

Political Science \& Politics

O стовеR 2017 , Vol U M 50 , N U M B R 4
The Politics and Pedagogy of Economic Inequality

Joel Westheimer, John Rogers, and Joseph Kahne, guest editors

Emotions, Ideologies, and Violent Political Mobilization

Stefano Costalli and Andrea Ruggeri, guest editors

Representation on the APSA Council: The Politics of Political Science

Amy Atchison, Jennifer Hochschild, and others on APSA Governance

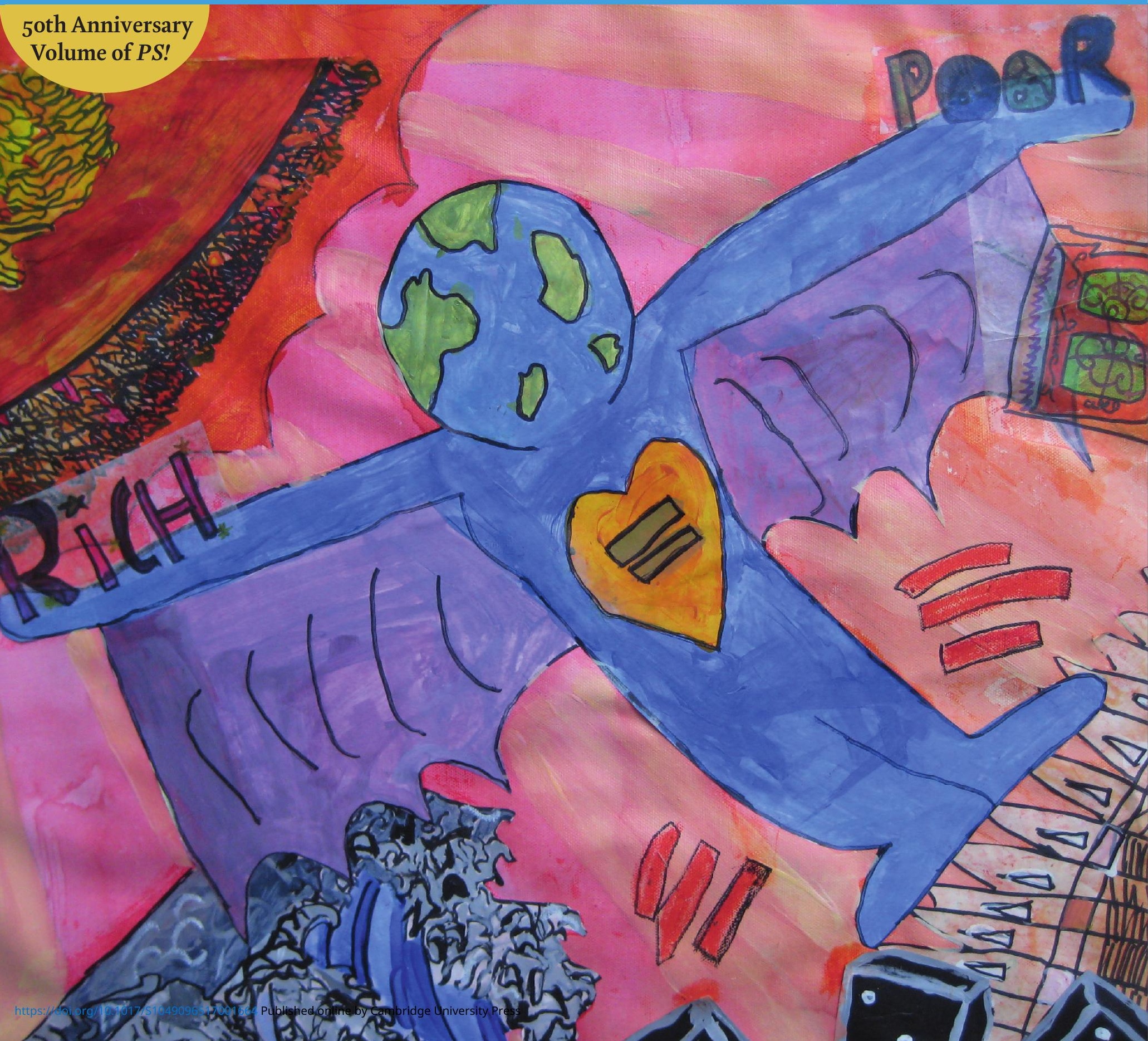




\section{Teaching Civic Engagement Across the Disciplines}

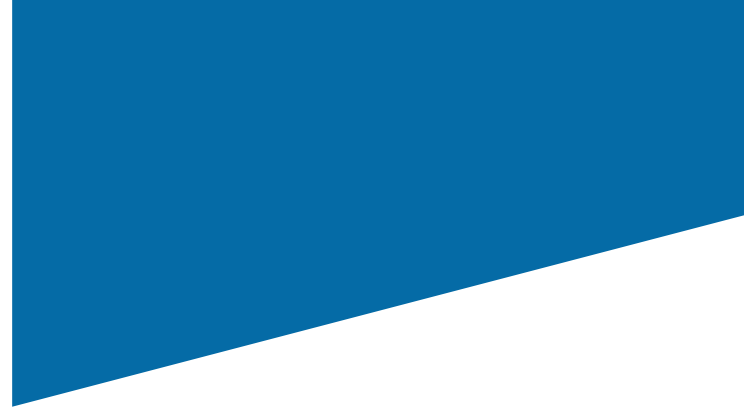

A new wave of civic instruction is moving through American education. As numerous national groups and institutions are joining this effort, political science is uniquely equipped to advance teaching civic engagement. The discipline should lead the movement for high quality civic education across the curriculum and across the disciplines.

To focus on this wave of civic engagement education, APSA is publishing the ebook Teaching Civic Engagement Across the Disciplines, edited by Elizabeth C. Matto, Rutgers University; Alison Rios Millett McCartney, Towson University; Elizabeth A. Bennion, Indiana University; and Dick Simpson, University of Illinois at Chicago.

The book redirects the focus from teaching better political science courses to teaching civic engagement across the disciplines. Building on the 2013 book Teaching Civic Engagement: From Student to Active Citizen, this book advances the conversation on civic engagement and provides critical scholarly insight into where to go next.

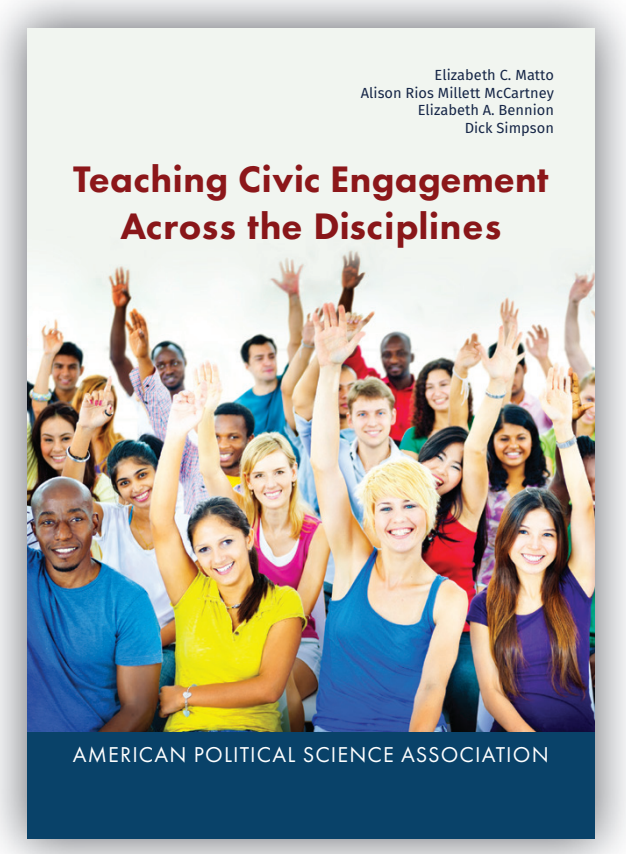

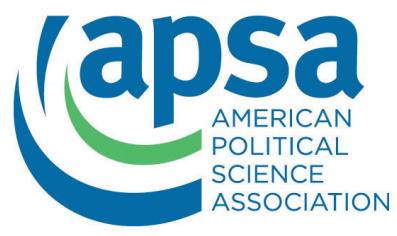

Read the book at www.apsanet.org/tce2 
913 Editors' Corner

Phillip Ardoin and Paul Gronke, with a Reflection note by Micheal Giles and James Garand

\section{LETTERS TO THE EDITORS}

917 Mismatch between (Some of) APSA and (Some) Political Scientists?

Jennifer Hochschild

With responses from Rogers M. Smith, Sara L. Parker, Michelle Deardorff, and Steven Rathgeb Smith

921 Young Scholars Development Program

Laura Reese

SYMPOSIUM

923

928

932 Emotions as the Residue of Lived Experience

Roger Petersen

936 Radicalization and Violent Emotions

Jacquelien van Stekelenburg

940 Emotional Distress, Conflict Ideology, and Radicalization

Daphna Canetti

944 Organizing Emotions and Ideology in Collective Armed Mobilization Francesco N. Moro

$948 \quad$ Ideology in Armed Groups

Livia Isabella Schubiger and Matthew Zelina

ARTICLES 953 Could President Trump Rely on Legal Advice to Order the Offensive Use of Military Force at His Discretion?

Chris Edelson

958 Big Data and Democracy: Facts and Values

Ashley E. Gorham

Does Peer Review Identify the Best Papers? A Simulation Study of Editors, Reviewers, and the Scientific Publication Process Justin Esarey

970 The Politics of Presence in Academic Professional Associations: A Research Note on Governance at the APSA

Amy Atchison

979 Trends in Political Science Research and the Progress of Comparative Politics Matthew Charles Wilson 
SYMPOSIUM

985

990

993

1000

1004

1008

1011

SYMPOSIUM

1015

1019

1023

1028

1038
1032 Incorporating Space in Mulitmethod Research: Combining Spatial Analysis

Contentious Politics in the United States: What Role for Political Scientists? Guest Editors: Maryam Zarnegar Deloffre and Carrie Booth Walling

Introduction

Maryam Zarnegar Deloffre and Carrie Booth Walling

Confronting Hate Collectively

Elizabeth Levy Paluck and Michael Suk-Young Chwe

Engaging a Campus During a Tumultuous Election: A Case Study

Carrie P. Eaves and Jason A. Husser

Building Civic Environments to Empower Citizens

Amy Widestrom

Activism in an Era of Partisan Polarization

Michael T. Heaney

Social Media and the Scholar in an Era of Hyper-Nationalism and Fake News Joshua Busby

Speaking Rights To Power

Alison Brysk

Finding Agency in the Margins: Lessons from Teaching as Immigrant

Women of Color

Bidisha Biswas and Shirin Deylami

The Road Less Traveled: An Agenda for Mixed-Methods Research Guest Editors: Marissa Brookes, Kendra Koivu, Sara Niedzwiecki, and Jennifer Cyr

Introduction

Marissa Brookes

Case Studies and Analytic Transparency in Causal-Oriented Mixed-Methods Research Jeb Barnes and Nicholas Weller

Cases of Convenience? The Divergence of Theory from Practice in Case Selection in Qualitative and Mixed-Methods Research Kendra L. Koivu and Annika Marlen Hinze

Mixed-Methods Research in the Study of Welfare States Sara Niedzwiecki and David Nunnally with Case-Study Research Imke Harbers and Matthew C. Ingram

The Unique Utility of Focus Groups for Mixed-Methods Research Jennifer Cyr
The Politics and Pedagogy of Economic Inequality Guest Editors: Joel Westheimer, John Rogers, and Joseph Kahne

1043 Introduction Joel Westheimer, John Rogers, and Joseph Kahne

1049 Teaching About Economic Inequality in a Diverse Democracy: Politics, Ideology, and Difference John Rogers and Joel Westheimer 
1056 Facing Facts in an Era of Political Polarization: Young People's Learning and Knowledge about Economic Inequality Benjamin Bowyer and Joseph Kahne

1062 The Invisible Hand of History: Pluralism, Power, and Inequality Lisa García Bedolla and Jessica Andrade

1068 Promoting Elementary School-Age Children's Understanding of Wealth, Poverty, and Civic Engagement

Rashmita S. Mistry, Lindsey Nenadal, Taylor Hazelbaker, Katherine M. Griffin, and Elizabeth $S$. White

1074 The Politics and Pedagogy of Economic Inequality: A Short Contribution James K. Galbraith

1077 What Should High School Students Know? Bill Bigelow, Katherine Cramer, Patrick Garry, Jesse Hagopian, Gloria Ladson-Billings, Anand R. Marri, Pedro Noguera, Tamara Sober, and Mackenzie Wall

ARTICLES 1083 Pushing the Envelope of Pedagogical Gaming: Dark Networks Michael E. Freeman

1089 Teaching across Cultures: Student-Led Modules in a Human Rights Course Becca McBride

1094 Creative Writing and the Study of Politics Susan McWilliams

1099 Campus Teaching Awards, Academic Year 2016-2017

\section{THE ASSOCIATION}

$\begin{array}{lll}\text { PEOPLE } & 1103 & \text { Spotlights } \\ & 1104 & \text { PS Update } \\ 1105 & \text { Books by Our Readers } \\ 1107 & \text { In Memoriam }\end{array}$

BUSINESS 1115 Shift Happens: The Historical Institutionalism of Kathleen Thelen

1120 Nominations Accepted for the 2018 APSA Awards

1121 Highlights from PS: Political Science \& Politics Editors' Report, 2016-2017

1125 Meet the 2017-2018 Minority Fellows

11292017 Recipients of the Fund for Latino Scholarship

1131 Briefs

1132 Next in $P S$

1133 APSA Publishes New Book on Civic Engagement Education

1136 APSA Members of the Month

GAZETTE 1137

APSA Awards Presented at the 2017 Annual Meeting

ANNUAL MEETING

Annual Meeting and Exhibition Review

1148 APSA Awards

1152 Teaching Civic Engagement Across the Disciplines

11532017 APSA Ralph Bunche Scholars Present iPosters

1154 Graduate Students and Scholars Funded

11562017 APSA Organized Section Awards Presented

1173 Corrigendum 
EDITORS: Phillip Ardoin, Appalachian State University Paul Gronke, Reed College

MANAGING EDITOR: Celina Szymanski

EDITORIAL ASSOCIATE: Drew Meadows

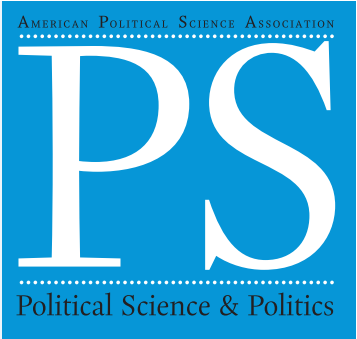

EDITORIAL BOARD:

Lindsay Benstead, Portland State University; Jeffrey Bernstein, Eastern Michigan University; Michelle Bropy Baermann, Rhode Island College; James E. Campbell, University at Buffalo, SUNY; R. Scott Crichlow, West Virginia University; Michelle Deardorff, University of Tennessee, Chattanooga; Mary Durfee, Michigan Tech; James C. Garand, Louisiana State University; Kristin Goss, Duke University; J. Tobin Grant, Southern Illinois University; Todd K. Hartman, University of Sheffield; John Ishiyama, University of North Texas; David Kinsella, Portland State University; Amber R. Knight, Saint Louis University; Peter Lindsay, Georgia State University; Samantha Majic, John Jay College of Criminal Justice; Elizabeth Markowitz, Mount Holyoke; Kristin Michelitch, Vanderbilt University; Joanne M. Miller, University of Minnesota; Megan Ming Francis, University of Washington; James E. Monogan III, University of Georgia; Jennifer Nicoll Victor, George Mason University; Mark Carl Rom, Georgetown University; Bartholomew Sparrow, University of Texas-Austin; Brent Steele, University of Utah; Charles R. Venator-Santiago, University of Connecticut; Ismail White, George Washington University; Betina C. Wilkinson, Wake Forest University; Jason Windett, Saint Louis University.

ASSOCIATION OFFICE ADDRESS AND MEMBERSHIP INFORMATION:

American Political Science Association individual membership dues are: regular members with income $\$ 200,000+, \$ 325 ;$ \$135,000-199,999, \$276; \$100,00o-134,00o, \$246; \$8o,000-99,999, \$212; \$6o,ooo-79,999, \$191;

$\$ 50,000-59,999, \$ 175 ; \$ 40,000-49,999, \$ 145 ;$ under $\$ 40,000, \$ 98$; retired members $\$ 25,000+, \$ 66$; retired under $\$ 25,000, \$ 40$; targeted international member (TIM), \$45; life member, $\$ 4,000$; associate member, one journal, $\$ 75$; high school teacher ( $P S$ only), $\$ 50$; student member, $\$ 52$; unemployed member, $\$ 45$. The amount of the dues allocated for a subscription is $\$ 5.75$ for an individual membership.

Changes of address for members should be completed online or mailed to the APSA membership office at: APSA, 1527 New Hampshire Avenue, NW, Washington, DC 20036-1206.

SUBSCRIPTION, PUBLISHING, AND ADVERTISING OFFICE ADDRESS:

Cambridge University Press, One Liberty Plaza, 2oth Floor, New York, NY 10006; and (outside North America) Cambridge University Press, University Printing House, Shaftesbury Road, Cambridge CB2 8BS, England.

SUBSCRIPTION INFORMATION: PS: Political Science \& Politics (ISSN 1049-0965) is published in January, April, July, and October by Cambridge University Press for the American Political Science Association. PS: Politica Science $\mathcal{E}$ Politics is sold only as part of a joint subscription with American Political Science Review and Perspectives on Politics. Annual institutional electronic-only subscription rate (2017) is US\$1563 in the United States, Canada, and Mexico, UK£898 elsewhere. Annual institutional print-and-electronic subscription rate (2017) is US $\$ 1812$ in the United States, Canada, and Mexico, UK $£ 1028$ elsewhere. Periodicals postage rate paid at New York, NY, and additional mailing offices. POSTMASTER: Address changes should be sent to: PS: Political Science \& Politics, Cambridge University Press, One Liberty Plaza, 2oth Floor, New York, NY 10006.

Copyright (C) 2017 by the American Political Science Association. All rights reserved. No part of this publication may be reproduced, in any form or by any means, electronic, photocopying, or otherwise, without permission in writing from Cambridge University Press. Photocopying information for users in the USA: The Item-Fee Code for the publication (1049-0965/17 $\$ 15.00+\$ .10)$ indicates that copying for internal or personal use beyond that permitted by Sec. 107 or 108 of the U.S. Copyright Law is authorized for users duly registered with the Copyright Clearance Center (CCC) Transaction Reporting Service, provided that the appropriate remittance of $\$ 15.00$ per article is paid directly to CCC, 222 Rosewood Drive, Danvers, MA 01923. Specific written permission must be obtained for all other copying. ADVERTISING: PS has a circulation of 16,00o. Please contact our Advertising Sales Team at USAdSales@cambridge.org for full advertising information including rates and specs.

COMPOSITION: TNQ Books and Journals Pvt. Ltd.

PRINTING AND DISTRIBUTION: The Sheridan Press 


\section{About APSA}

Founded in 1903, the American Political Science Association is the leading professional organization for the study of political science and serves more than 13,000 members in over 80 countries. With a range of programs and services for individuals, departments, and institutions, APSA brings together political scientists from all fields of inquiry, regions, and occupational endeavors within and outside academe in order to deepen our understanding of politics, democracy, and citizenship throughout the world.

The direct advancement of knowledge is at the core of APSA activities. We promote scholarly communication in political science through a variety of initiatives including publishing four distinguished journals: American Political Science Review, Perspectives on Politics, PS: Political Science \& Politics, and Journal of Political Science Education.

\section{Officers}

\section{PRESIDENT}

David Lake

University of California,

San Diego

\section{PRESIDENT-ELECT}

Kathleen Thelen

Massachusetts Institute

of Technology

\section{VICE-PRESIDENTS}

Janet Box-Steffensmeier

Ohio State University

Elaine Kamarck

Brookings Institution

Ian Shapiro

Yale University

\section{SECRETARY}

Marion Orr

Brown University

\section{TREASURER}

Taeku Lee

University of California, Berkeley

\section{PROGRAM CO-CHAIRS}

Amaney Jamal

Princeton University

Susan Stokes

University of California, Berkeley

LEAD EDITOR, APSR

Thomas König

University of Mannheim

EDITOR, PERSPECTIVES

Jeffrey Isaac

Indiana University

EXECUTIVE DIRECTOR

Steven Rathgeb Smith

\section{Council}

2015-2017

Roxanne Euben

Wellesley College

Amaney Jamal

Princeton University

Brett Ashley Leeds

Rice University

James Mahoney

Northwestern University

Byron D'Andra Orey

Jackson State University

Bo Rothstein

University of Gothenburg

Cameron Thies

Arizona State University

Caroline Tolbert

University of Iowa

2016-2018

Matt Barreto

University of California,

Los Angeles

Mark Crescenzi

University of North Carolina,

Chapel Hill

Omar Encarnación

Bard College

Kristian Gleditsch

University of Essex

Juliet Hooker

University of Texas, Austin

Colleen Shogan

Library of Congress

Renée Van Vechten

University of Redlands

Christina Wolbrecht

University of Notre Dame

\section{Former APSA Presidents}

Frank J. Goodnow

Albert Shaw

Frederick N. Judson

James Bryce

A. Lawrence Lowell

Woodrow Wilson

Simeon E. Baldwin

Albert Bushnell Hart

W. W. Willoughby

John Bassett Moore

Ernst Freund

Jesse Macy

Munroe Smith

Henry Jones Ford

Paul S. Reinsch

Leo S. Rowe

William A. Dunning

Harry A. Garfield

James W. Garner

Charles E. Merriam

Charles A. Beard

William Bennett Munro

Jesse S. Reeves

John A. Fairlie

Benjamin F. Shambaugh

Edward S. Corwin

William F. Willoughby

Isidor Loeb

Walter Shepard

Francis W. Coker

Arthur N. Holcombe

Thomas Reed Powell

Clarence A. Dykstra

Charles Grove Haines

Robert C. Brooks

Frederic A. Ogg

William Anderson

Robert E. Cushman

Leonard D. White

John Gaus

Walter F. Dodd

Arthur W. MacMahon

Henry R. Spencer

Quincy Wright

James K. Pollock

Peter H. Odegard

Luther Gulick

Pendleton Herring

Ralph J. Bunche

Charles McKinley

Harold D. Lasswell

E. E. Schattschneider

V. O. Key, Jr.

R. Taylor Cole

Carl B. Swisher

Emmette S. Redford
Charles S. Hyneman

Carl J. Friedrich

C. Herman Pritchett

David B. Truman

Gabriel A. Almond

Robert A. Dahl

Merle Fainsod

David Easton

Karl W. Deutsch

Robert E. Lane

Heinz Eulau

Robert E. Ward

Avery Leiserson

Austin Ranney

James MacGregor Burns

Samuel H. Beer

John C. Wahlke

Leon D. Epstein

Warren E. Miller

Charles E. Lindblom

Seymour Martin Lipset

William H. Riker

Philip E. Converse

Richard F. Fenno

Aaron B. Wildavsky

Samuel P. Huntington

Kenneth N. Waltz

Lucian W. Pye

Judith N. Shklar

Theodore J. Lowi

James Q. Wilson

Lucius J. Barker

Charles O. Jones

Sidney Verba

Arend Lijphart

Elinor Ostrom

M. Kent Jennings

Matthew Holden, Jr.

Robert O. Keohane

Robert Jervis

Robert D. Putnam

Theda Skocpol

Susanne Hoeber Rudolph

Margaret Levi

Ira Katznelson

Robert Axelrod

Dianne M. Pinderhughes

Peter Katzenstein

Henry E. Brady

Carole Pateman

G. Bingham Powell, Jr.

Jane Mansbridge

John H. Aldrich

Rodney E. Hero

Jennifer Hochschild 


\section{Achieving Diversity and Inclusion in Political Science}

\section{Diversity and Inclusion Programs}

The American Political Science Association has several major programs aimed at enhancing diversity within the discipline and identifying and aiding students and faculty from underrepresented backgrounds in the political science field. These programs include:

Ralph Bunche Summer Institute (RBSI) (Undergraduate Juniors)

The RBSI Program is an annual five-week program designed to introduce undergraduate students from under represented racial/ethnic groups, or students interested in broadening participation in political science and pursuing scholarship on issues affecting under-represented groups, to the world of graduate study and to encourage application to PhD programs. Application deadline: January of each year. For more information, visit www.apsanet.org/rbsi.

APSA Minority Fellows Program (MFP) (Undergraduate Seniors or MA and PhD students) (Fall Cycle for seniors and MA Students, Spring Cycle for PhD students) MFP is a fellowship competition for those applying to graduate school, designed to increase the number of individuals from under-represented backgrounds with PhD's in political science. Application deadline: October and March of each year. For more information, visit www.apsanet.org/mfp.

Minority Student Recruitment Program (MSRP) (Undergraduates and Departmental members) The MSRP was created to identify undergraduate students from under-represented backgrounds who are interested in, or show potential for, graduate study and, ultimately, to help further diversify the political science profession. For more information, visit www.apsanet.org/msrp.

\section{APSA Mentoring Program}

The Mentoring Program connects undergraduate, graduate students, and junior faculty to experienced and senior members of the profession for professional development mentoring. APSA membership is required for mentors. To request a mentor or be a mentor, visit www.apsanet.org/mentor.

\section{APSA Status Committees}

APSA Status Committees develop and promote agendas and activities concerning the professional development and current status of under-represented communities within the political science discipline. For a listing of all APSA status committees, visit www.apsanet.org/status-committees.

For more information on all Diversity and Inclusion Programs, visit us online at www.apsanet.org/ diversityprograms. Please contact Kimberly Mealy, PhD, Senior Director of Diversity and Inclusion Programs with any questions: kmealy@apsanet.org.

To contribute to an APSA Fund, such as the Ralph Bunche Endowment Fund or the Hanes Walton Jr. Fund, visit us at www.apsanet.org/donate. 